\title{
IMAGINED DESTINIES
}




\title{
IMAGINED DESTINIES Aboriginal Australians and the Doomed Race Theory, 1880 - 1939
}

\author{
Russell McGregor
}

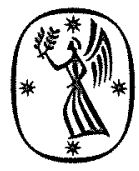

MELBOURNE UNIVERSITY PRESS 
Melbourne University Press

PO Box 278, Carlton South, Victoria 3053, Australia

First published 1997

Text $@$ Russell McGregor 1997

Design and typography (C) Melbourne University Press 1997

This book is copyright. Apart from any use permitted under the Copyright Act 1968 and subsequent amendments, no part may be reproduced, stored in a retrieval system or transmitted by any means or process whatsoever without the prior written permission of the publisher.

Typeset by Syarikat Seng Teik Sdn. Bhd. in 10/13 pt Sabon Printed in Malaysia by SRM Production Services Sdn. Bhd.

National Library of Australia Cataloguing-in-Publication entry

McGregor, Russell, 1955-

Imagined destinies: Aboriginal Australians and the doomed race theory, 1880-1939.

Bibliography. Includes index.

ISBN 0522847625.

1. Aborigines, Australian-Treatment-History. 2. Aborigines. Australian-Government relations. 3. Australia-Race relations -History. I. Title.

306.0899915 


\section{Contents}

$\begin{array}{lr}\text { Preface } & \text { ix } \\ \text { Acknowledgements } & \begin{array}{r}\text { xiii } \\ \text { xiv }\end{array} \\ \text { Conversions } & 1 \\ \text { Prologue: The Eclipse of Antipodean Enlightenment } & 19 \\ 1 \text { The Creation and Annihilation of Primitive Man } & 60 \\ 2 \text { Protection and Preservation } & \\ 3 \text { Anthropology Renovated, Optimism Revived and } & 100 \\ \text { Problems Renewed } & 142 \\ 4 \text { Civilisation by Blood } & 181 \\ 5 \text { Progress for All } & 224 \\ 6 \text { New Solutions, Old Assumptions } & 261 \\ \text { Abbreviations } & 262 \\ \text { Notes } & 288 \\ \text { Bibliography } & 307\end{array}$




\section{Illustrations}

Plates 1, 2 and 3 are photographs from Walter Baldwin Spencer's 1923 'Report on the Half-castes and Aboriginals of the Southern Division of the Northern Territory'.

Plates 4, 5 and 6 are photographs from Dr W. D. Walker's 1928 Report.

Plates 6 to 12 are photographs from J. W. Bleakley's inquiry into 'The Aboriginals and Half-castes of Central Australia and North Australia'. 


\section{Preface}

For the greater part of the past two hundred years, white Australians believed the indigenous inhabitants doomed to extinction. It was not that extinction was considered possible, or probable, or contingent upon certain courses of action; nor was it merely that Aboriginal numbers were observed to be declining. Extinction was regarded as the Aboriginals' inescapable destiny, decreed by God or by nature.

This idea took root in Australia in the early decades of the nineteenth century, flourishing in its latter years and in the early twentieth century. By the period between the two world wars, the doomed race idea was showing signs of withering, although it persisted, albeit with declining vigour, until at least the 1950s. Throughout these years, the expectation of extinction exerted a powerful influence over white Australian attitudes toward, and interactions with, the Aboriginals. Even as it declined, the doomed race theory cast a long shadow over the newly-emerging proposals for securing an Aboriginal future.

In this book I explore the doomed race concept, its intellectual underpinnings and its eventual undermining. White Australians' assurance of the Aboriginal demise derived not so much from knowledge of demographic trends as from suppositions that had become firmly entrenched in the Western imagination since the Enlightenment of the eighteenth century. In particular, it was the entanglement of the idea of progress with the concept of race that lent credibility to the prediction of inevitable extinction. The prediction gradually lost credibility as the concepts of race and progress were hesitantly and tentatively disentangled. 
This book traces the changing renditions of these ideas in the writings of scientists, humanitarian reformers, missionaries, administrators and others who made public comment on the destiny of the Aboriginals. Consideration of administrative matters is confined largely to a single jurisdiction, the Northern Territory, although some attention is given to the status of Aboriginals within the broader parameters of Commonwealth legislation. Temporally, the study covers the period from 1880 to 1939 . The former date marks not the beginnings of the doomed race theory but its consolidation, by the evolutionary science of the late nineteenth century. The latter date marks the beginning of World War II, the repercussions of which were to upset long-established assumptions about the significance of race. For this reason, and because by 1939 the inevitability of extinction was as much contested as conceded, it is a convenient year at which to conclude.

Many of the ideas and assumptions I examine are today regarded as not merely wrong but also reprehensible. However, since my purpose is to explicate these ideas within their social and cultural contexts, I have refrained from pronouncing on their morality or correctness. The doomed race concept once exerted a pervasive influence over relations between black and white Australians; it seems more appropriate now to elucidate the meanings and significance of that concept than to condemn its evident shortcomings. Explication and elucidation have problems of their own, for ambiguity, ambivalence, incoherence and contradiction pervade white Australian discourses on the Aboriginals. Yet the ambiguities were as important as the affirmations, the equivocations as significant as the definitive declarations. The breakdown of the doomed race theory was slow, hesitant and faltering; and as it declined new problems and fears arose in the imaginations of white Australians.

The endeavour to understand the past in terms of the ideas and assumptions then current necessitates use of the terminology of the past. Words such as 'progress', 'primitive', 'civilisation', 'savagery', 'advanced', 'backward', 'uplift' and 'degeneration' appear frequently in this work, along with the terms 'half-caste', 'fullblood', 'part-Aboriginal' and 'mixed-blood'. These words are not enclosed within quotation marks except in quotation or, as in the 
preceding sentence, where the words themselves rather than their conceptual referents are the issues under consideration. Lack of quotation marks in no way indicates endorsement of the conceptual world to which such terms pertained.

In all quoted passages, emphases-italics, upper-case lettering and so forth-replicate those in the original documents.

I have made no attempt to force the vocabulary of non-sexist language into explications of the various texts, as it seems inappropriately anachronistic to impose the sensitivities of the late twentieth century upon writings from a different age. Since Darwin wrote of the 'descent of man', I too refer to 'man' in discussing his ideas.

The spelling of Aboriginal words has not been standardised or modernised; instead, I use whatever spelling was adopted by the writer under discussion. Thus in chapter 6 a group now conventionally designated the 'Warlpiri' is rendered the 'Wailbri', following the usage of the anthropologist under consideration, Olive Pink.

This book is not a history of Aboriginal Australians; it is a history of textual representations of Aboriginals. It begins with a Prologue, which sketches out the origins of the doomed race theory in the early colonial period. Chapter 1 examines the construction of evolutionary anthropology in Britain and Australia, before exploring the ways in which evolutionary ideas consolidated the expectation that the Aboriginal race would soon be extinct. In chapter 2 the focus shifts to the administration of Aboriginal affairs in the Northern Territory, suggesting that contemporary protectionist policies offered a glimmer of hope for the survival of the race. The centrepiece of this chapter is an analysis of the writings of the eminent evolutionary anthropologist, Walter Baldwin Spencer, in his role as Chief Protector of Aborigines in the Northern Territory in 1912.

Chapter 3 sketches out three themes that are examined more thoroughly in the following chapters: the changing orientation of anthropology in the years after World War I; the gradual decline of certainty in the Aboriginal demise; and the marked rise in the level of concern over persons of mixed descent. In chapter 4 the focus is 
on what was then termed the 'half-caste problem', which was effectively the obverse of racial extinction. Chapter 5 uses the writings of A. P. Elkin, Professor of Anthropology at the University of Sydney, to explore the faltering growth of the notion that Aboriginals may be able to advance to the stage of civilisation and the status of Australian citizens. The disproportionate attention devoted to Elkin reflects his importance, both as a leading Australian anthropologist and as an adviser to governments, missionaries and humanitarian bodies. Disagreement over the destiny of the Aboriginals is the subject of chapter 6. Although the doom of the race appeared less certain by the 1930 s, there was no unanimity on how survival could best be ensured or on the place of the survivors in the Australian nation. The doomed race theory was itself heading toward extinction; in the process, the Aboriginal destiny became increasingly a matter of dispute. 


\section{Acknowledgements}

Thanks are due first and foremost to my wife, Christine Mitchell, for her support and encouragement, for her comments on earlier drafts of the manuscript, and for her patience and forbearance as the enterprise came to its long-awaited end.

May Carlson, Julie-Ann McLeod, Rob Smail and Barbara van Houts provided invaluable support to my own very meagre abilities at the computer keyboard. I am indebted to Henry Reynolds for his advice and encouragement throughout the researching and writing of the manuscript. I wish also to thank Larry Crook, Brian Dalton, Kett Kennedy, Noel Loos, Tracey McAskill, Dianne Menghetti, Anne Smith, Rod Sullivan and Paul Turnbull for their various contributions.

The assistance of the staff of the following institutions is gratefully acknowledged: Australian Archives, Canberra; Australian Institute of Aboriginal and Torres Strait Islander Studies; Australian National Library; James Cook University Library, Townsville; La Trobe Library, Melbourne; Mitchell Library, Sydney, Public Records Office of South Australia; South Australian Museum Anthropology Archives; University of Adelaide Archives; University of Sydney Archives. 


\section{Conversions}

In 1972 metric measurements were adopted in Australia:

$\begin{array}{ll}1 \text { inch } & 2.54 \text { centimetres } \\ 1 \text { foot } & 30.5 \text { centimetres } \\ 1 \text { yard } & 0.91 \text { metre } \\ 1 \text { mile } & 1.61 \text { kilometres } \\ 1 \text { acre } & 0.405 \text { hectare } \\ 1 \text { pound } & 0.45 \text { kilogram }\end{array}$

On 14 February 1966 Australian currency changed from pounds, shillings and pence $(£, s, d)$ to dollars and cents at the rate of $£ 1=\$ 2$. Twelve pence made up one shilling; twenty shillings made up one pound; twenty-one shillings made up one guinea. 


\section{PROLOGUE \\ The Eclipse of Antipodean Enlightenment}

Only a year after the arrival of the First Fleet at Botany Bay, Captain Watkin Tench published a brief 'Description of the Natives of New South Wales'. In the opening paragraph he invited the reader 'to contemplate the simple, undisguised workings of nature, in her most artless colouring'. That the Aboriginal represented man* in a state of nature, Tench seems to have felt no need to justify or explain. People who lived by hunting and fishing, naked and homeless, were simply presumed to approximate the natural condition of humanity. Admitting that his knowledge of the natives was fragmentary and incomplete, he recounted some of their customs and means of livelihood. ${ }^{1}$ Although Tench's ethnography was somewhat rudimentary, the assumption that Aboriginals were in, or close to, a state of nature was to enjoy a very long vogue. With the expansion of colonial enterprise to the antipodes, Europeans had discovered the best living exemplars of natural man.

In his 1793 book, A Complete Account of the Settlement at Port Jackson, Tench provided a more detailed and considered description of the natives. Here, the Enlightenment concept of savagery, as a stage in the early history of all mankind, was more salient than in his earlier brief account. So too was the Enlightenment notion that a savage people's failure to advance derived not from innate deficiencies but from the lack of environmental stimuli to progress. If the Aboriginals 'be considered as a nation', Tench wrote, 'they certainly rank very low, even in the scale of savages'. But, he continued,

* See p. xi. 
if from general view we descend to particular inspection, and examine individually the persons who compose this community, they will certainly rise in estimation ... The behaviour of Arabanoo, of Baneelon, of Colbee, and many others, is copiously described; and assuredly he who shall make just allowance for uninstructed nature, will hardly accuse any of those persons of stupidity, or deficiency of apprehension.

To offer my own opinion on the subject, I do not hesitate to declare, that the natives of New South Wales possess a considerable portion of that acumen, or sharpness of intellect, which bespeaks genius. All savages hate toil, and place happiness in inaction: and neither the arts of civilized life can be practised, or the advantages of it felt, without application and labour. ${ }^{2}$

Two features of this passage are worthy of comment. In the first place, Tench clearly appreciated the distinction between generalisations about a people's way of life and assessments of the individuals who lived in that manner. This simple distinction was to become clouded with the later rise of a science of inherent racial attributes. Secondly, in associating savagery with indolence and civilisation with labour, Tench was in line with a prominent strand of Enlightenment thought. For the educated person of the eighteenth century, it was the application of labour to the production of the necessities and superfluities of life that set civilised man apart from the savage. More specifically, it was the cultivation of the soil that was the necessary badge of civilisation.

By the late eighteenth century the Enlightenment idea of progress had crystallised into an assumption that societies followed a natural developmental sequence, from a stage of savagery (characterised by hunting as the mode of subsistence) to one of barbarism (characterised by nomadic pastoralism) to civilisation (distinguished by agriculture and commerce).

Both the French and the Scottish proponents of stadial theory defined the various stages according to mode of subsistence, though the Scots tended to give greater weight to economics as the motivating factor of progress. Accordingly, savages remained in 
the hunting stage because their societies had not been subjected to such pressures as overgrown population or inadequate lands over which to range, or because their environment offered no suitable animals and plants for domestication. But whatever the factors impelling people to progress from one stage to the next, the notion that there was a natural sequence of developmental stages was well established by the end of the eighteenth century. ${ }^{3}$

A key feature of stage theory was its interpretation of the superiority of one society over another in temporal terms. Europeans had long considered the civilised superior to the savage. What was novel in the Enlightenment tradition was the supposition that savagery had given rise, through a natural sequence of progressive development, to civilisation.

Tench's representation of the Aboriginals was set within a framework of Enlightenment ideas of societal development. However, he had no time for that alternative Enlightenment vision, best represented by Rousseau, which held out the noble savage as an exemplar of human virtues. As an English gentleman, Tench was horrified by the 'savage barbarity' with which Aboriginal men treated women. From this, he went on to declaim:

A thousand times ... have I wished, that those European philosophers, whose closet speculations exalt a state of nature above a state of civilisation, could survey the phantom, which their heated imaginations have raised: possibly they might then learn, that a state of nature is, of all others, least adapted to promote the happiness of a being, capable of sublime research, and unending ratiocination...

Aboriginals, he contended, were like all savages in being easily swayed by 'the impulse of the moment'; among their negative qualities, 'their levity, their fickleness, their passionate extravagance of character, cannot be defended'. The Aboriginal 'form of government' was 'strictly a system of Equality, attended with only one inconvenience-the strong triumph over the weak'. Yet this lowly state of society was not equated with a bestial manner of life.

On their religious ideas, Ténch expressed his 'firm belief, that the Indians of New South Wales acknowledge the existence of a 
superintending deity'. Admitting that their spiritual beliefs were heavily laden with magic and superstition, he explained: 'Until belief be enlightened by revelation, and chastened by reason; religion and superstition, are terms of equal import'. Like all human thought, religious belief was subject to a process of improvement.

On Aboriginal languages, Tench admitted the inadequacy and incompleteness of his understanding, but was confident that they were structured and expressive like any other human language. He noted the regular inflection of nouns and verbs, and the fact that noun cases and verb tenses were denoted, as in Latin, 'by change of termination'. The sounds of the Aboriginal languages he described as 'sometimes mellifluous, and sometimes sonorous', although at other times 'harsh and barbarous'. The major deficiency he noted was the lack of numerals above four; but unlike many later commentators he did not extrapolate from this any deficiency in the Aboriginal intellect. Possessing the distinctive human attributes of religion and language, Aboriginals were undoubtedly members of the same human family as Europeans.

Tench entertained no doubt about the superiority of his own civilisation and the inferiority of Aboriginal savagery. Yet he perceived beneath these superficial differences a universal human nature. His account ended on a note resonant with the Enlightenment principles of reason, progress, and the unity of mankind:

let those who have been born in more favoured lands, and who have profited by more enlightened systems, compassionate, but not despise, their destitute and obscure situation. Children of the same omniscient paternal care, let them recollect, that by the fortuitous advantage of birth alone, they possess superiority: that untaught, unaccommodated man, is the same in Pall Mall, as in the wilderness of New South Wales: and ultimately let them hope, and trust, that the progress of reason, and the splendor of revelation, will in their proper and allotted season, be permitted to illumine, and transfuse into these desert regions, knowledge, virtue, and happiness. ${ }^{4}$ 
Like Tench, Judge-Advocate David Collins came out to New South Wales on the First Fleet. Also like Tench, Collins set his account of the Aboriginals within a framework of Enlightenment ideas of societal development, beginning with the remark that he 'found the natives ... living in that state of nature which must have been common to all men previous to their uniting in society, and acknowledging but one authority'. Collins, however, better exemplifies the detached scientific observer of indigenous peoples. His remarks on the Aboriginals were neatly arranged under various headings: 'Government and Religion', 'Stature and Appearance', 'Habitations', 'Mode of Living' and so forth, each dealing with the designated issue from as dispassionate a perspective as could be expected of an eighteenth-century English gentleman. Acknowledging that Aboriginals, as individuals, displayed the same diversity of character as other peoples, Collins described their disposition, taken as a whole, as 'revengeful, jealous, courageous, and cunning'. Although the characterisation was ambivalent, he concluded his account on a note of restrained hopefulness, suggesting that the Aboriginals were not 'wholly incapable of becoming one day civilized and useful members of society'. ${ }^{5}$

Yet ideas of a universal human nature and of a universal human capacity to attain civilisation were not the only intellectual currents to emerge from the eighteenth century. The ancient concept of the Great Chain of Being enjoyed a resurgence, as an ordering principle of biology. Traditionally, the Great Chain had been employed to express the plenitude of God's creation by arranging nature into a vast hierarchy, from inanimate matter through to the simple organisms and on to man at the apex, or perhaps beyond, to the angels. Each link on the Chain was differentiated from its neighbours by only small variations, so that the whole comprised a continuous scale expressive of the harmony of creation. As Europeans became increasingly familiar with the diversity of humankind-and with the anthropoid apes-the gap in the Chain between man and monkey was able to be filled in, with black races at the bottom of the human link, closest to the highest simian. ${ }^{6}$ 
The idea of the Great Chain was familiar to some of the early Australian colonists. The naval surgeon, Peter Cunningham, included it in his musings on the status of the Aboriginals; they were, he wrote,

lively, good-humoured, inquisitive, and intelligent, and are found to acquire the knowledge of reading, writing, \&c., almost as expertly as Europeans. If their intellectual functions, then, are thus so far above debasement, how is it that the abject animal state in which they live, and their great and glaring deficiency in all the useful mechanical arts (in comparison with other savages), should place them at the very zero of civilisation, constituting in a measure the connecting link between man and the monkey tribe?

However, in answering his own rhetorical question, Cunningham repudiated the notion that Aboriginals were mere animals, emphasising instead the importance of environmental influences. Elaborating his argument, he provided one of the finest antipodean expressions of the Enlightenment vision of human progress:

Civilisation depends more upon the circumstances under which man is placed than upon any innate impulse of his own, the natural inclinations of man tending toward the savage state, or that in which food is procured with the least possible effort; there being something so irresistibly captivating in a wild, roaming life of this description, that few who have made the trial ever relish civilised society thoroughly again. It is only necessity that urges mankind to congregate in fixed habitations, and raise their food by the sweat of their brow; for if it could still be procured in as easy a way by civilised Europeans as by our uncultivated tribes, the European woods would soon abound with creatures nearly as rude and idle as our natives...

It is, I repeat, the necessity springing from over-grown population, and difficulty in obtaining food, except by artificial means, that first drives man into taking up a fixed abode; but here neither of these causes operates. 
Cunningham maintained that Aboriginals could become civilised, although he cautioned that this may take generations, as 'the wild feeling inherent in them must have time to wear out'. ${ }^{7} \mathrm{He}$ may merely have toyed with the idea of the Great Chain; other colonists embraced it wholeheartedly.

Over the course of the eighteenth century, a science of race was under construction. In Linnaeus's taxonomy of 1735 humanity was divided into four races, distinguished by a combination of physical, psychological and social traits. Drawing on the idea of the Great Chain, Linnaeus placed both human beings and the apes within the order Quadrumana. This classification, along with the idea of the Great Chain, was rejected by the leading late eighteenth-century authority on racial taxonomy, Johann Friedrich Blumenbach. Although Blumenbach insisted that man was fundamentally distinct from all other animals, his studies were of Homo sapiens as a biological species; although he repudiated the Great Chain, he persisted in the hierarchical ordering of races. A similar stance was adopted by the eminent British ethnologist James Cowles Pritchard.

Both Blumenbach and Pritchard held to the religiously orthodox view that all races had descended from Adam and Eve. This monogenist perspective, however, did not entail a belief in racial equality. Fundamentally, all humanity was one; but upon that underlying unity, variations had been elaborated, and the races that embodied those variations could be ranked on a scale of worth. More extreme views on racial inequality were propounded by the polygenists, who took the religiously unorthodox line that the fundamental and unbridgeable differences between races indicated that they were the products of separate creations. In Britain the monogenist viewpoint was dominant in racial science until at least the fourth decade of the nineteenth century. ${ }^{8}$ More moderate than polygenists in their stance on racial differences, monogenist theories still allowed ample scope for representing other peoples as inferior.

Barron Field, Judge of the New South Wales Supreme Court, endorsed Professor Blumenbach's 'most philosophic division of the varieties of the human species' into the Caucasian, Mongolian, 
Ethiopian, Malayan and American races. However, Field disputed the German anatomist's classification of the Australians with the Malayan race, claiming instead that the 'skull, the genius, the habits, of the Australians appear to me, as far as I have been able to investigate the subject, to have, in all of them, the degenerate Ethiopian character'. The revised classification was of considerable importance, for according to Blumenbach's theory the Ethiopian was a more degenerate type than the Malayan.

Going one step further, Field bluntly asserted that 'the Australian will never be civilized'. He was convinced that there was something inherent in the Aboriginal constitution that predisposed them to the life of the 'hunter and fisher'. Although the nature of this innate quality was not clearly explained, he did allude to the Aboriginals' lack of certain mental qualities necessary for the attainment of civilisation: 'They have quick conceptions, and ready powers of imitation; but they have no reflection, judgement or foresight'. ${ }^{9}$

Phrenology played a significant part in fostering the notions that Aboriginal mental powers were limited and their prospects for improvement slight. Although phrenology had a meliorative element, its principles displayed an overt biological determinism, perhaps most of all when applied at a group rather than an individual level. ${ }^{10}$ The populariser of phrenology in the English-speaking world, George Combe, studied Australian skulls, concluding that their brains were 'distinguished by great deficiencies in the moral and intellectual organs'. It was impossible to civilise the Aboriginals as the 'organs of reflecting intellect, Ideality, Conscientiousness and Benevolence' were 'greatly inferior in size'. There was no lack of colonial commentators who agreed with, and elaborated upon, these ideas. ${ }^{11}$ On the other hand, there were those who condemned such manifestly materialistic doctrines. The missionary Lancelot Threlkeld fulminated against phrenology, as 'a splendid specious fallacy leading away the mind from the hope of the influence of God's holy spirit'. ${ }^{12}$ Threlkeld may have repudiated scientific materialism; but missionaries of his stamp were themselves not innocent of peddling derogatory images of the Aboriginal. 
Traditionally, the Christian view emphasised the unity of humankind, as all were eligible for the grace of God. Evangelicals of the early nineteenth century, however, dwelt upon the innate sinfulness of man and on the consequences of the Fall. The majority of early colonial missionaries were Evangelicals. The Wesleyan Reverend William Walker encapsulated the pessimism of the Evangelical outlook in his statement that Aboriginals were 'the progeny of him who was cursed to be "a servant of servants to his brethren"'.13 Emphasising the fallen state of man, Evangelicals interpreted the lowly condition of the Aboriginals as the outcome of their degeneration. After observing some rock engravings on the central New South Wales coast, Threlkeld remarked that it was 'evident from these very engravings upon the rocks that the aborigines have degenerated'. He then reflected on the possibility of 'very ancient buildings lying hid in Australia', the remains of a lost civilisation. ${ }^{14}$ Such musings were not confined to the Evangelicals. In the early nineteenth century, widespread credibility attached to the notion that Aboriginal society illustrated not the original condition of man but the ultimate depths of human degradation.

In his 1846 Remarks on the Probable Origin and Antiquity of the Aboriginal Natives of New South Wales colonial magistrate William Hull utilised both Enlightenment stage theory and the concept of savagery as regression. In Hull's version of stadial theory societies could move down the snake of degeneration, as well as up the ladder of progress. The Aboriginals, in his view, had declined from a formerly more civilised state to one of wretched savagery, impelled on their downward course by the power of irrational superstition. Indeed, the central thrust of Hull's argument was to demonstrate the potency of superstition as a degenerative force. Thus he rejected the biological explanations for Aboriginal inferiority that had then come into vogue, along with the notion, derived from the Great Chain, that they were a connecting link between man and monkey. Such ideas he considered both derogatory to the blacks and an impediment to a true understanding of humanity. If his own account emphasised how 'low in moral degradation [and] intellectual power' the Aboriginals had sunk, he none the less insisted that they must be remembered as having once 
occupied 'a higher relative position as regards mankind'. ${ }^{15}$ Hull held out no hope that they would ever regain it.

For those colonists who maintained a belief that Aboriginals could become civilised, there were more pressing reasons to refute the notion that the race was by nature inferior and bestial. Robert Dawson, manager of the Australian Agricultural Company, was adamant that Aboriginals were 'capable of civilization', and advocated that 'experiments' be made to prove the point. He continued:

If, however, they are not, as some assert, of the same creation, and therefore a different species of humanity; or if, as others think, they are only a third, fourth, or fifth link in the same creation, and the nearest of all to the monkey or the orangoutang tribe, and therefore incapable of enjoying the same state of intellectual existence as themselves, all experiments would be useless.

Dawson added that 'happily for the natives all their white brethren do not entertain these degrading and absurd opinions. ${ }^{16}$ But many did.

A decade after Dawson wrote, the great colonial explorer and imperial administrator, George Grey, put forward his proposals for civilising the Aboriginals. Grey explained that although the laws and customs of the Australians were 'barbarous', the people themselves were none the less capable of advancement: 'for many races who were at one period subject to the most barbarous laws, have, since new institutions have been introduced amongst them, taken their rank among the civilized nations of the earth'. Realising that civilising efforts could be successful only if Aboriginal ability and adaptability were acknowledged, he repudiated the many accounts that 'most unfairly represented [them] as a very inferior race, in fact as one occupying a scale in the creation which nearly places them on a level with the brutes'. He added that 'some years must elapse, ere a prejudice so firmly rooted as this can be altogether eradicated' ${ }^{17}$ His hopefulness that the prejudice would be uprooted was misplaced; far from losing ground, it became more and more firmly entrenched. 
By the time Dawson and Grey wrote, they had to counter not only the racial theories of the day but also the pragmatic argument that all previous endeavours to civilise the Aboriginals had failed. Within the first year of colonisation, Captain Arthur Phillip had attempted to civilise a local Aboriginal, Arabanoo; after initial success in mastering English manners and language, Arabanoo died of smallpox. Phillip's next experiment was scarcely more encouraging. One of the subjects, Colbee, ran away; the other, Bennelong, after becoming sufficiently civilised to visit London, returned to his own country only to be rejected by both white and black societies. In the very first years of the nineteenth century the Reverend Samuel Marsden attempted to civilise two young Aboriginal boys by raising them with his own family. They learned to read and write, but disappointed Marsden with their lack of filial devotion. Perhaps it was for this reason that he came to the conclusion that 'nothing can be done' to civilise the Aboriginals, for 'however young when taken by the Europeans, [they] will not submit to any Restraint, as soon as they can range the woods'.

In 1814 Governor Lachlan Macquarie established a Native Institution at Parramatta, for the purpose of 'Educating, and bringing up to Habits of Industry and Decency, the Youth of both Sexes'. He also attempted to induce Aboriginals to adopt the habits of settled agriculturalists by making grants of land available to them, along with instruction in the requisite skills. Neither attempt was attended with success. ${ }^{18}$ Alluding to this history of failure, Barron Field wrote:

We have now lived among the [Aboriginals] for more than thirty years and the most persevering attempts have always been made, and are still making, to induce them to settle, and avail themselves of the arts of life; but they cannot be fixed, nor is it possible by any kindness or cherishing to attach them. They have been brought up by us from infancy in our nurseries, and yet the woods have seduced them at maturity, and at once elicited the savage instincts of finding their food in the trees, and their path through the forest,--propensities which civil education had only smothered. ${ }^{19}$ 
For Field, all this was evidence of their inability to ever become civilised.

Yet there were those who maintained that these failures derived not from Aboriginal deficiencies but from defects in the methods employed. Cunningham argued that the major problem with Macquarie's Institution lay in segregating the native from the white children. He advocated instead that Aboriginal children should be housed in Orphan Asylums, 'where, mixing with a numerous population of white children, they will gradually imbibe their ideas, and manners and customs too'.20

By the 1820 s those who still believed that Aboriginals could be civilised held widely differing opinions on how it should be attempted. Some commentators insisted that Aboriginal advancement would best be served by their immediate employment in socially useful roles. Others argued for their temporary segregation from white society, shielding them from its vices until they had been sufficiently inculcated with its virtues. ${ }^{21}$ There were those who claimed Christianisation to be the necessary first step toward civilisation. The Assistant Protector of Aborigines at Port Phillip, James Dredge, regarded instruction in the Christian religion as the 'only infallible plan for effecting their civilization'. Others put their faith in secular reforms. George Grey maintained that civilising the Aboriginals depended on their being made amenable to British law; in his view, Christian conversion was a noble and necessary duty, but the law came first. ${ }^{22}$

By the 1820 s the question of whether Christianity should precede attempts to civilise, or vice versa, was being debated within colonial missionary circles. ${ }^{23}$ Although there were exceptions, the dominant view within the clergy was that Christianity must come first. Commentators of more secular outlook were more likely to assert the alternative option. Peter Cunningham, for example, argued that changes in the form of government and in the means of subsistence were essential before any higher religious ideas could be inculcated. ${ }^{24}$ The Polish explorer, Paul Strzelecki, was more forthright, proclaiming that 'since the first dawn of human history, the civil organisation of society has preceded its religious and moral instruction'. Criticising the missionaries for their attempts 
to introduce a religion that had no meaning within the context of Aboriginal society, he argued that 'the holy doctrine which the missionaries preached to the aborigines sapped the foundations of their normal government, and its dissolution followed. The voice of Christianity, of disinterested, spiritual religious faith, was rendered ineffectual by civil disorganisation'. Yet while Strzelecki depicted the Aboriginals in humane terms, he was not hopeful that any method would successfully bring about their civilisation; 'it will be easier', he emphasized, 'to bring the whites down to the level of the blacks, than to raise the latter to the ideas and habits of our race'. 25

Ultimate pessimism in Aboriginal capacities to advance found expression in the idea that they were doomed to inevitable extinction. In this view, the coming of civilisation to Australian shores, far from leading the indigenes to a higher social state, could result only in their demise. Interestingly, the earliest colonial commentators, like Tench and Collins, made no reference to the possibility of extinction, despite the fact that they witnessed the terrible decimation of the Port Jackson tribes in the first smallpox epidemic of 1789. The growth of an expectation of extinction correlated closely with declining faith in Aboriginal abilities to become civilised. In 1825 Barron Field expressed his sentiments on the 'extermination of the simple race of Australia' in verse:

Yet deem not this man useless,

But let him pass, - a blessing on his head!

...

May never we pretend to civilize,

And make him only captive!

Let him be free of mountain solitudes;

And let him, where and when he will, sit down

Beneath the trees, and with his faithful dog

Share his chance-gather'd meal; and, finally,

As in the eye of Nature he has lived,

So in the eye of Nature let him die! ${ }^{26}$

Field was certainly not the last to pen romantic verses on the passing of the Aboriginal race. And he was not alone in arguing that 
with extinction their ultimate fate, the Aboriginals could be most kindly treated by leaving them to their accustomed ways.

By the 1830s the doomed race concept had gained a more secure place in the colonial imagination. There were those like George Grey who held out against it, but for the majority of colonial commentators there appears to have been something irresistibly attractive in the notion of inevitable Aboriginal extinction. For writers like Threlkeld and Hull, who believed the Aboriginals to be the debased remnants of a formerly civilised people, extinction could be regarded as the end point of the degenerative process. Threlkeld maintained that not only had the Aboriginals degenerated, but they would 'continue so to do, until the few remaining individuals shall have become extinct, like many other portions of the human family, who are now no more'. ${ }^{27}$ If this implied that Aboriginals were on the road to extinction before the colonisation of their country, Threlkeld did not deny that the European presence was a contributing factor.

In his overview of contemporary attitudes toward Aboriginals, William Westgarth provided a representative selection of the various factors that were commonly adduced to explain the trend toward extinction:

The causes of this gradual extinction appear to be tolerably ascertained; their own mutual wars; their hostile encounters with the whites; the diseases and vices of European society, unusually destructive in their effects, from irregularity in the mode of life, and the want of proper medical treatment; the common practice of infanticide; and, more remotely, perhaps, by the gradual disappearance of various animals used as food, and of other sources of their support. ${ }^{28}$

Yet to many inquiring minds, physical causes alone seemed inadequate to explain so awesome a process as racial extinction. Herman Merivale, lecturing at Oxford in the 1840s, remarked on the inadequacy of these materialistic explanations, claiming that there were 'deeper and more mysterious causes at work; the mere contact of Europeans is fatal to him in some unknown manner'. ${ }^{29}$ In similar vein, Charles Darwin recorded in his journal in 1836 
that as well as the 'several evident causes of destruction' of the Aboriginals, there appeared 'to be some more mysterious agency generally at work' ${ }^{30}$

According to many, the mysterious agency was the hand of God. Giving evidence before a Select Committee of the Legislative Council of Victoria in 1858, William Hull explained that it is the design of providence that the inferior races should pass away before the superior races ... since we have occupied the country, the aborigines must cease to occupy it'. ${ }^{31}$ Less reverently, Paul Strzelecki described prevailing colonial opinion on the matter:

Those in whose eyes the question of decrease and extinction has assumed all the mournful solemnity and interest which it merits, have inquired into the nature of that invisible but desolating influence, which, like a malignant ally of the white man, carries destruction wherever he advances; and the inquiry, like an inquest of the one race upon the corpse of the other, has ended, for the most part, with the verdict of, 'Died by the visitation of God'.

Despite the sarcasm, Strzelecki adhered to the notion that the Aboriginal race was doomed to inevitable extinction.

Attempting to fashion an adequate explanation for the process, Strzelecki provided one of the more comprehensive early nineteenth-century accounts of the doomed race theory. He noted that various writers had attributed the decline of the Aboriginal population 'to the want of evangelical instruction, to oppressive governments, to intemperance, to European diseases, to wars with fire-arms, \&c'. However, the inadequacy of such explanations was demonstrated by the fact that all attempts to remedy these problems had tended merely 'to increase, rather than diminish, the evils complained of'. Strzelecki claimed instead that the cause of the decline lay not in an 'increased rate of mortality', but in a 'decrease of births'. The available facts, he argued, 'render it evident that their longevity has not been abridged, that the rate of mortality has not increased, but that the power of continuing or procreating the species appears to have been curtailed'. The 'most remarkable' aspect of this decline in fertility was that after having sexual 
intercourse with a European male 'the native female is found to lose the power of conception on a renewal of intercourse with the male of her own race, retaining only that of procreating with the white men'. In describing this phenomenon, Strzelecki was reduced to such adjectives as 'mysterious' and 'occult'. Resuming a more sedate tone, he went on to remark that the impact of venereal disease would be still more devastating, as it led to 'absolute sterility in the native female ${ }^{32}$

Two aspects of Strzelecki's explanation are worthy of further comment. The first is his emphasis on sexual intercourse as the most potent cause of the Aboriginal demise. A linkage between the means of human reproduction and the mechanisms of racial extinction was to persist through the many and varied renditions of the doomed race theory, long after the specifics of Strzelecki's theory had been discredited.

The second and related issue concerns what was meant by racial extinction. Strzelecki's version actually required the production of half-caste offspring; and if other commentators were not necessarily as explicit as this, it was none the less the case that the propagation of people of mixed descent in no way ran counter to the doomed race idea. It was not predicted that Aboriginals would leave no descendants at all; merely that they would leave none of the full descent.

Explaining the process by which Aboriginals were 'becoming extinct', Threlkeld drew attention to miscegenation, remarking that 'in a generation or two more the pure aborigines of these parts will be numbered amongst the numerous extinct nations' ${ }^{33}$ For the godly, the existence of half-castes may have been a standing rebuke to the moral standards of many colonists; but they were never seen as evidence against the idea that the Aboriginals were doomed to die out.

Lack of comprehensive demographic data appears to have been no impediment to the firm conviction that the demise of the Aboriginal race was inevitable. For some limited areas, accurate statistics on the Aboriginal population were compiled. Beyond that, population details were not-indeed could not be-known. Casual observation doubtless revealed that with the expansion of 
European settlement, the Aboriginal population diminished, sometimes rapidly. But observed population decline is very different to a prediction of inevitable extinction. The doomed race idea, it seems, drew its major sustenance from sources other than hard demographic data. At a popular level, the Aboriginal death toll that was consequent upon their dispossession could be conveniently explained away as an inevitability of nature or of the Divine plan. Yet the condoning of acts of violence was not the only morality that could be extracted from the terrible prospect of racial extinction.

Many of the most eloquent proponents of the doomed race idea were men of strong humanitarian views, who were horrified by what they saw of the brutal treatment of Aboriginals. Barron Field was disgusted by the notion that Aboriginals could be killed merely because they were members of an inferior race. ${ }^{34}$ Strzelecki believed that because the Aboriginals had 'the sentence of extinction stamped indelibly upon their foreheads', it was incumbent upon the government to render that process 'less painful'. This, he thought, could best be done by the honest declaration of the Aboriginals as a conquered people, by leaving intact the traditional tribal organisation, and by providing the people with regular and adequate rations. His humanitarian romanticism is evident in the words he claimed to be the wishes of the 'remaining few' Aboriginals:

Leave us to our habits and customs; do not embitter the days which are in store for us, by constraining us to obey yours; nor reproach us with apathy to that civilisation which is not destined for us; and if you can still be generous to the conquered, relieve the hunger which drives us in despair to slaughter your flocks and the men who guard them. Our fields and forests, which once furnished us with abundance of vegetable and animal food, now yield us no more; they and their produce are yours. You prosper on our native soil, and we are famishing! ${ }^{35}$

Threlkeld provides a fine example of a philanthropic adherent to the doomed race idea. As a missionary he spent thirty-five years of 
his life ministering to both the spiritual and the physical needs of the Aboriginals. He was appalled by the violent treatment meted out to Aboriginals on the frontiers of settlement, and took a prominent part in bringing the infamous Myall Creek massacre, and similar punitive expeditions, to official attention. Threlkeld held a hope that a small number of Aboriginals may be 'called to the acknowledgment of the truth as it is in Jesus', before the race entirely passed away. ${ }^{36}$ But that they would entirely pass away, with or without Jesus, he was quite confident.

The doomed race theory was neither merely a sop for disturbed consciences nor an empirical demographic prediction. More than anything else, it was a manifestation of ultimate pessimism in Aboriginal abilities. As the Enlightenment vision of universal human progress faded, as attempts to civilise and convert failed, and as racial attitudes hardened, it came to be considered that the best that could be done for the Aboriginals was to protect them from overt injustice and brutality-for the short time they had left upon this earth. If, as increasingly came to be taken for granted, the Aboriginals were incapable of attaining the status of civilisation, they were equally incapable of living within a civilised community. 